$B J M G 11 / 2(2008) 31-38$

$10.2478 / \mathrm{v} 10034-008-0025-\mathrm{x}$

ORIGINAL ARTICLE

\title{
ANALYSIS OF THE SRY GENE IN TURNER SYNDROME PATIENTS FROM THE REPUBLIC OF MACEDONIA
}

\author{
Papazovska-Cherepnalkovski A, Koceva S, Kocova $M^{*}$
}

\begin{abstract}
*Corresponding Author: Mirjana Kocova, M.D., Ph.D., Department of Endocrinology and Genetics, University Pediatric Clinic, Vodnjanska 17, 1000 Skopje, Republic of Macedonia; Tel.: +389-2-3147-474/+389-70-242-694; Fax: +389-2-3129-027; e-mail: mirjanakocova@yahoo.com
\end{abstract}

\begin{abstract}
Turner syndrome is characterized by short stature, gonadal dysgenesis and a variety of somatic features and major organ malformations. About $50 \%$ of the patients have a 45,X karyotype, while the remainder have structurally abnormal sex chromosomes or mosaicism including mos 45,X/46XY. Those with Y chromosomal material are at increased risk for developing gonadoblastoma or dysgerminoma later in life. The SRY gene on Yp has a major role in sexual differentiation, being the primary testicular determinant. Detection of the SRY gene in Turner syndrome patients has important clinical and therapeutic implications.

We performed a genetic study of 40 Turner syndrome patients for cytogenetics ( $\mathrm{G}$ banding) and polymerase chain reaction (PCR) for the SRY gene using XES7/XES2 and SRY 1F/SRY 2R primer sets. Cytogenetics identified a $45, \mathrm{X}$ karyotype in $50 \%$, isochromosomes in $25 \%$, proximal long or short arm deletions and markers in $7.5 \%$ and mos $45, \mathrm{X} / 46 \mathrm{XY}$ in $5 \%$ of the patients. The SRY gene was detected in blood leucocytes of only two of the patients with the mos 45,X/46XY karyotype. Our low incidence of SRY-gene positive results in Turner syndrome patients contrasts with reported studies using more sensitive techniques that have detected a higher per-
\end{abstract}

Department of Endocrinology and Genetics, University Pediatric Clinic, 1000 Skopje, Republic of Macedonia centage. The increased risk of gonadoblastoma and the necessity of timely referral for gonadectomy require that analysis of the SRY gene should be offered to all Turner syndrome patients.

Key words: Karyotype, SRY gene, Turner syndrome

\section{INTRODUCTION}

Turner syndrome is one of the most common chromosomal abnormality syndromes [1], affecting 1 in 2,500 live born females. It is characterized by short stature, gonadal dysgenesis, a variety of somatic features (neck webbing, cubitus valgus, high arched palate, short neck and widely spaced nipples) and major organ malformations (e.g., congenital heart disease, structural renal abnormalities) $[2,3]$. Nearly half of the patients have a classical $45, \mathrm{X}$ karyotype, while the remainder have structurally abnormal sex chromosomes or are mosaics with cell lines including mos 45,X/46XY [4-6]. The percentage of mosaicism with a cell line that contains a normal or abnormal Y chromosome is about $5.5 \%$ using cytogenetic analysis [6]. Approximately half of the unidentifiable marker chromosomes that have an estimated frequency of 3\% are Y-derived [6,7]. It has been speculated that most Turner syndrome patients with putative non mosaic 45, X karyotype have an undetected mosaicism, based on an analysis which revealed that less than $1 \%$ of 45 , X conceptions survive pregnancy [8]. Several investigators have postulated that in $45, \mathrm{X}$ patients, fetal survival needs 
mosaicism in at least some organ or tissue $[8,9]$. Patients with the SRY gene require special attention since the presence of a $\mathrm{Y}$ chromosome correlates with a $10-20 \%$ risk of developing gonadoblastoma or dysgerminoma later in life $[10,11]$. Gonadoblastoma is an in situ malignancy of the dysgenetic gonad with variable age of appearance and considerable malignancy potential, and dysgerminomas and other malignant germ cell tumors can arise within the gonadoblastoma $[10,11]$. The critical region for development of gonadoblastoma has been tentatively localized to a $1-2 \mathrm{Mb}$ region near the centromere of the Y chromosome [12].

Sex determination and differentiation are sequential processes regulated by an unknown number of gene loci located on sex and autosomal chromosomes that occur in the testis-determining pathway. The SRY gene on Yp, a single exon gene that codes for a protein of the HMG-box-domain family of DNA-binding proteins has been shown to play a major role in sexual differentiation, being the primary testicular determinant [13-20].

Kocova et al. [21], reported that the SRY gene is present in about $33.3 \%$ of Turner syndrome patients, using the Southern blot technique after polymerase chain reaction (PCR). Others have shown a variable percentage of SRY gene-positive Turner syndrome patients [5,7]. Detection of this gene in patients with or without cytologically-detected sex-chromosome mosaicism has important clinical and therapeutic implications [21,22]. Using a combination of conventional cytogenetic methods and molecular DNA analysis for the SRY gene, we have studied 40 Turner syndrome patients from the Republic of Macedo- nia to estimate the frequency of $\mathrm{Y}$ mosaicism and compare our results with those in the literature.

\section{MATERIALS AND METHODS}

Patients. Of the 40 Turner syndrome patients we studied, 36 were hospitalized or out patients of the Department for Endocrinology and Genetics at the University Pediatric Clinic in Skopje, Republic of Macedonia, and four were out-patients of the University Clinic for Adult Endocrinology in Skopje. Inclusion criteria were a typical phenotype of Turner syndrome and the result of cytogenetic analysis. The mean age was 16 years.

Cytogenetic Analyses. Peripheral blood lymphocytes were examined by $\mathrm{G}$ banding (banding resolution of 400 bands, average number of observed metaphase preparations, 50).

DNA Extraction. Genomic DNA was extracted from 2-6 $\mathrm{mL}$ ethylenediamine tetraacetate-containing blood using a standard phenol-chloroform procedure from peripheral blood leucocytes [23,24] and from one formalin- treated and paraphine-embedded ovarian sample [25] extirpated due to endometrial malignancy.

Polymerase Chain Reaction Amplification. Two sets of oligonucleotide primers were used: XES7/ XES2 and SRY 1F/SRY 2R. XES7 5'-GAC AAT GCA ATC ATA TGC TTC TGC-3'/XES2 5'-CTG TAG CGG TCC CGT TGCT GCG GTG-3' amplify a $609 \mathrm{bp}$ fragment that spans almost the entire open reading frame (ORF) of the SRY gene $[4,5,26,27]$ (Figure 1). SRY 1F 5'-CAG TGT GAA ACG GGA GAA AAC AGT-3'/SRY 2R 5'-CTT CCG ACG AGG

\section{SRY gene}

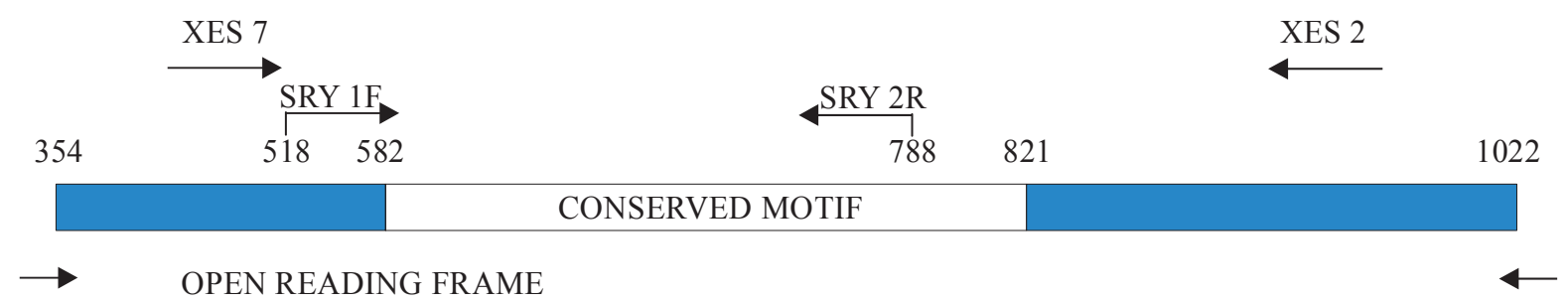

Figure 1. The structure of the SRY gene, showing in the middle third (582-821 bp), the HMG-box domain that codes for a highly conserved protein with DNA-binding characteristics and a putative role in transcriptional regulation. The SRY 1F/SRY 2R primer pair amplifies a $270 \mathrm{bp}$ fragment of DNA that extends between 518 and $788 \mathrm{bp}$. The open reading frame extends from 354 to $1022 \mathrm{bp}$. The XES7/XES2 primer pair amplifies a $609 \mathrm{bp}$ fragment of this frame. 
TCG ATA CTT ATA-3' amplify a 270 bp fragment (518-788 bp) that mainly encompasses the HMG-box domain, an evolutionary highly conserved motif that codes for a protein with DNA-binding characteristics [27] (Figure 1). The primers were synthesized in Sigma Genosys (Sigma-Aldrich Corporation, St. Louis, MO, USA). Amplification of a $165 \mathrm{bp}$ fragment of the angiotensinogen gene or a $458 \mathrm{bp}$ fragment of the CFTR gene were used as controls. The sequences of the primer pairs used to amplify the internal controls were: F 5'-CAG GGT GCT GTC CAC ACT GGA CCC C-3'/R 5'-CCG TTT GTG CAG GGC CTG GCT CTC T-3' for the first fragment, and F 5'-TCA CAT ATG GTA TGA CCC TC-3'/R 5'-TTG TAC CAG CTC ACT ACC TA-3' for the second fragment.

The PCR amplification was performed in a final volume of $50 \mu \mathrm{L}$, the reaction mixture consisting of 300-500 ng genomic DNA, 50 pmol of each specific primer and 30 pmol of the control primers, $1.5 \mathrm{U} \mathrm{Am-}$ pliTaq Gold polymerase (Applied BioSystems, Foster City, CA, USA), $2 \mathrm{mM} \mathrm{MgCl}, 200 \mu \mathrm{M} 4 \times \mathrm{dNTP}$, commercial PCR buffer. The amplification was carried out with a DNA thermal cycler (Perkin Elmer 480 version 2; Perkin Elmer Corporation, Waltham, MA, USA); 33 cycles with different programs for each primer set (XES7/XES2: $94^{\circ} \mathrm{C}, 10 \mathrm{~min} ., 9^{\circ} \mathrm{C}$, 45 seconds, $60^{\circ} \mathrm{C}, 1 \mathrm{~min}$., $72^{\circ} \mathrm{C}, 2 \mathrm{~min}$.; SRY 1F/ SRY
2R: $94^{\circ} \mathrm{C}, 10 \mathrm{~min} ., 94^{\circ} \mathrm{C}, 45$ seconds, $58^{\circ} \mathrm{C}, 1 \mathrm{~min}$, $72^{\circ} \mathrm{C}, 2 \mathrm{~min}$.) (amplification conditions were based on a method previously reported [27] and self- adjusted temperatures).

Analyses of the Polymerase Chain Reaction Amplified Products. All PCR products $(10 \mu \mathrm{L})$ were electrophoresed on a $2 \%$ agarose gel in $1 \times$ TBE buffer stained by ethidium bromide and visualized under UV light. Several precautions were taken to avoid falsepositive results [7]. All laboratory procedures were performed by a female operator, thus excluding the possibility for sample contamination with male cells. Pre- and post-PCR work spaces were strictly separated so that carry-over of amplified DNA sequences to new PCR reactions were prevented. Each PCR reaction contained one normal female and one templatefree sample for early detection of contamination. Each PCR reaction included one normal male sample as a positive control.

\section{RESULTS}

The cytogenetic analyses revealed a $45, \mathrm{X}$ non mosaic karyotype in 50\%, isochromosomes in $25 \%$, proximal long or short arm deletions in $7.5 \%$, markers in $7.5 \%$, mos $45, \mathrm{X} / 46 \mathrm{XY}$ in 5\% and other karyotypes in $5 \%$ of the patients (Table 1). The SRY gene

Table 1. Cytogenetic and molecular findings in the 40 Turner syndrome patients from Macedonia. ([-] indicates negativity for the SRY gene, $[+]$ indicates positivity for the SRY gene.)

\begin{tabular}{|l|c|c|c|c|}
\hline Karyotype & $\boldsymbol{n}$ & Frequency (\%) & SRY Gene & SRY HMG-Domain \\
\hline $45, \mathrm{X}$ & 20 & 50.0 & {$[-]$} & {$[-]$} \\
\hline $45, \mathrm{X} / 45, \mathrm{X}+\mathrm{mar}$ & 2 & 5.0 & {$[-]$} & {$[-]$} \\
\hline $46, \mathrm{X}, \mathrm{i}(\mathrm{Xq}) ; 45, \mathrm{X} / 46, \mathrm{X}, \mathrm{i}(\mathrm{Xq})$ & 4 & 10.0 & {$[-]$} & {$[-]$} \\
\hline $45, \mathrm{X}+\mathrm{r}$ & 1 & 2.5 & {$[-]$} & {$[-]$} \\
\hline $47, \mathrm{XXX} / 45, \mathrm{X}$ & 1 & 2.5 & {$[-]$} & {$[-]$} \\
\hline $46, \mathrm{XX},+\operatorname{mar}$ & 1 & 2.5 & {$[-]$} & {$[-]$} \\
\hline $46 \mathrm{XiX}$ & 5 & 12.5 & {$[-]$} & {$[-]$} \\
\hline $46, \mathrm{X}, \mathrm{i}(\mathrm{Xq}) / 46, \mathrm{X}, \operatorname{del}(\mathrm{X})(\mathrm{p} ?)$ & 1 & 2.5 & {$[-]$} & {$[-]$} \\
\hline $46, \mathrm{X}, \operatorname{del}(\mathrm{X})(\mathrm{q} ?)$ & 2 & 5.0 & {$[-]$} & {$[-]$} \\
\hline $46, \mathrm{X}, \operatorname{del}(\mathrm{X})(\mathrm{p} ?)$ & 1 & 2.5 & {$[-]$} & {$[-]$} \\
\hline $\operatorname{mos} 45, \mathrm{X} / 46 \mathrm{XY}$ & 2 & 5.0 & {$[+]$} & {$[+]$} \\
\hline
\end{tabular}


was detected only in two patients who had the mos 45,X/46XY karyotype, whereas all other patients were SRY negative (Table 1). The presence of an endometrial adenocarcinoma in a 21 -year-old patient with $45, \mathrm{X}$ karyotype and a negative SRY gene in both peripheral blood leucocytes and an ovarian sample raised high suspicions of unidentified $\mathrm{Y}$ chromosome sequences. However, a search for three additional loci in the AZF region on $\mathrm{Yq}(\mathrm{AZFb}, \mathrm{AZFa}$ and $\mathrm{AZFc}$ ) was negative, thereby excluding the possibility of an unidentified $\mathrm{Y}$ chromosomal mosaicism (data not shown).

We found an incidence of SRY-gene-positive results of $5 \%$ in Turner syndrome patients (Table 1). Figure 2 shows electrophoresis of PCR amplification products of a 270 bp SRY-gene-specific fragment using primers SRY 1F/SRY 2R. Figure 3 shows electrophoresis of PCR amplification products of a 609 bp SRY-gene-specific fragment using primers XES7/ XES2.

\section{DISCUSSION}

Cytogenetic analyses revealed various karyotype presentations in our patients. A classical 45,X non mosaic karyotype was identified in $50 \%$ of the patients, which corresponds to findings of other authors (40-60\%) [4-6]. However, the number of tissues and cells examined influenced detection of mosaicism. For example, when both peripheral lymphocyte and fibroblast cultures were evaluated, only $20.7 \%$ of karyotypes of 87 live born Turner syndrome patients were found to be 45,X [8]. We found unidentifiable marker chromosomes in $7.5 \%$ of the patients, which is much higher than previously reported (3\%) [5]. Our molecular analyses did not identify any of the markers as originating from the $\mathrm{Y}$ chromosome, whereas others have found up to $50 \%$ of markers to have Y chromosomal origin [7]. The difference of Y-chromosome-positive patients in different studies is caused by the different sensitivity of the methods applied.

Apparent association has been found between Y chromosome material (in sex-reversed females caused by deletion/mutation of the SRY gene or in Turner syndrome patients with Y chromosomal mosaicism) and an increased risk of appearance of gonadoblastoma in the dysgenetic gonad [11], which led to the hypothesis of a $\mathrm{Y}$ chromosomal locus

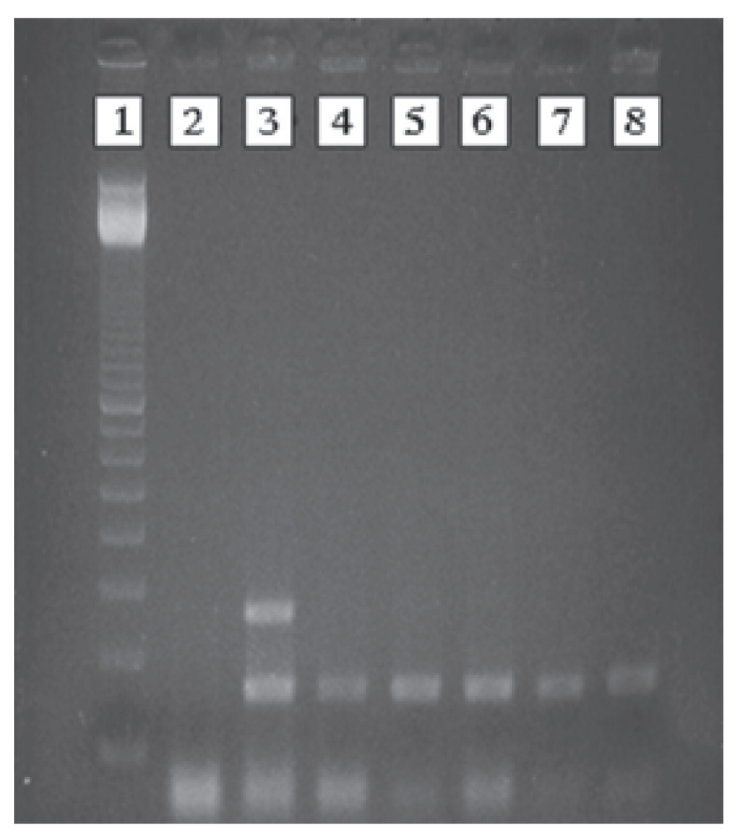

$\longleftarrow 270$ bp - SRY-gene-specific fragment

$\longleftarrow 165 \mathrm{bp}$ - control fragment

Figure 2. Agarose gel electrophoresis of the SRY gene-PCR products from four Turner syndrome patients amplified with SRY 1F/SRY 2R primers as described in Materials and Methods. Lane 1: 100 bp DNA ladder 100-2000 bp (Amersham Pharmacia Biotech Inc., Piscataway, NJ, USA), lane 2: template-free sample (negative control), lane 3: normal male sample (positive control), lane 4: normal female sample, lanes 5-8: patients 1-4 with various karyotype presentations (46XiX, 45,X/45,X+frag, 45,X and 46XiXp, respectively). 


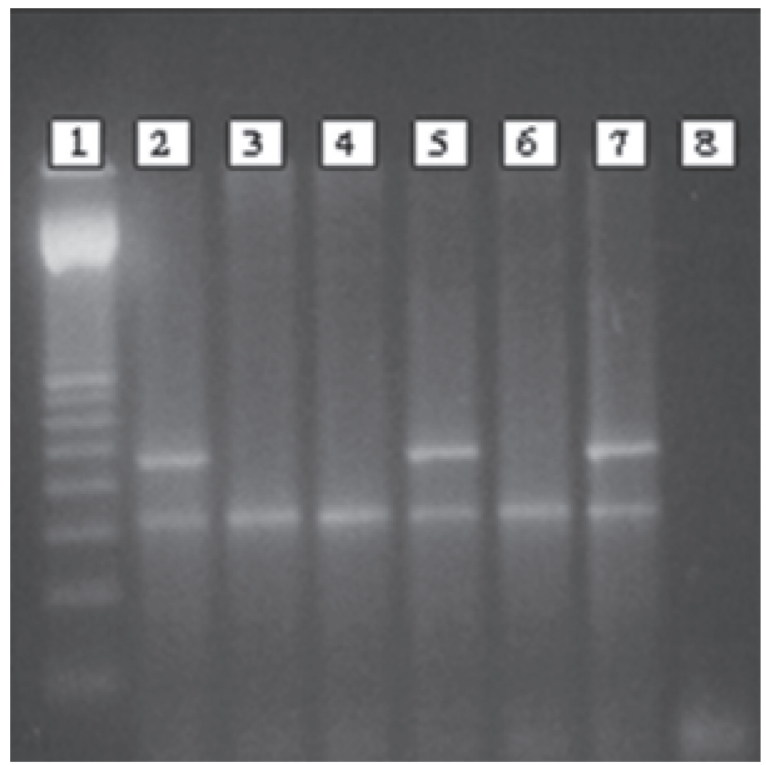

$\longleftarrow 609 \mathrm{bp}-$ SRY-gene-specific fragment

$\longleftarrow 485 \mathrm{bp}$ - control fragment

Figure 3. Agarose gel electrophoresis of the SRY gene-PCR products from four Turner syndrome patients amplified with XES7/XES2 primers as described in Materials and Methods. Lane 1: 100 bp DNA ladder 100-2000 bp (Amersham Pharmacia Biotech inc.), lane 2: normal male sample (positive control), lane 3: normal female sample, lanes 4-7: patients 1-4 with various karyotype presentations (46XiX/46XXp-, mos 45,X/46XY, 45,X and mos 45,X/46XY, respectively), lane 8: template-free sample (negative control).

(referred to as gonadoblastoma locus on the Y chromosome or GBY) that increases susceptibility to gonadoblastoma development [28]. Based on deletion mapping in phenotypic females with gonadoblastoma and partial Y chromosome, GBY was localized to a region near the centromere on either arm of the Y chromosome [28]. Detailed deletion mapping of the human $Y$ chromosome in 10 patients with gonadoblastoma, six having a rearranged $\mathrm{Y}$ chromosome, further localized the gonadoblastoma critical region to a 1-2 Mb of Yp near the centromere [12].

Pubertal virilization in some Turner syndrome patients represents an alarming sign of an undetected Y-chromo-some-positive cell line that increases the risk for development of gonadoblastoma. This raised the question of the diagnostic and therapeutic difficulties due to the small number of XY cells [21]. In this sense, detection of the SRY gene represents a valuable and sensitive method in detection of an unrecognized Y-chromosome-positive cell line and may alter the therapeutic approach.

We detected the SRY gene in peripheral blood leucocytes of two patients with the mos 45,X/46XY karyotype, whereas all other patients were SRY negative. This low incidence $(5 \%)$ of SRY-positive results in Turner syndrome patients agrees with the results of other studies $[29,7,26]$. One of these studies [26], cytogenetically detected two mosaics for a Y-chromosome-positive cell line in 41 patients examined, who were subsequently verified as SRYgene positive $(4.87 \%)$. More sensitive techniques have detected a higher percentage of SRY-gene positive patients (12 [5], 13.3 [30]). The sensitivity of SRY-PCR was increased through Southern blotting of the PCR products, a method that can detect one Ychromosome bearing cell in 100,000 cells and found $33.3 \%$ of Turner syndrome patients to be SRY-positive [21].

Epidemiological studies in Denmark have questioned the postulated high incidence of gonadoblastoma in Turner syndrome patients [31,32]. Nevertheless, because of the increased risk of gonadoblastoma in Turner syndrome patients with Y-chromosome material [11], the possibility of "low-level hidden" mosaicism for a Y-chromosome-positive cell line in the gonads, the variable age of expression [10], the high malignancy potential of gonadoblastoma and the necessity of timely referral for gonadectomy, analysis of SRY should be offered to all Turner syndrome patients.

We are aware that increased sensitivity of our technique can be obtained by using either a nested 
PCR, by transfer of the PCR products on a nylon membrane and hybridization with a labeled probe, or by adding additional probes for the Y chromosome. However, we aimed to establish a simple, easily reproducible, cost-effective and yet sufficiently sensitive method for SRY gene detection with a clinical applicability.

\section{REFERENCES}

1. Turner HH. A syndrome of infantilism, congenital webbed neck, and cubitus valgus. Endocrinology $1938 ; 28: 566-574$.

2. Saenger P. Turner's Syndrome. N Engl J Med 1996; 335(23): 1749-1754.

3. Saenger P, Albertsson Wikland K, Conway GS, Davenport M, Gravholt CH, Hintz R, Hovatta O, Hultcrantz M, Landin-Wilhelmsen K, Lin A, Lippe B, Pasquino AM, Ranke MB, Rosenfeld R, Silberbach M. Recommendations for the diagnosis and management of Turner syndrome. J Clin Endocrinol Metab 2001; 86(7): 3061-3069.

4. Canto P, de la Chesnaye E, Lopez M, Cervantes A, Chavez B, Vilchis F, Reyes E, Ulloa Aguirre A, Kofman Alfaro S, Mendez JP. A mutation in the 5' non-high mobility group box region of the SRY gene in patients with Turner syndrome and Y mosaicism. J Clin Endocrinol Metab 2000; 85(5):1908-1911.

5. López M, Canto P, Aguinaga M, Torres L, Cervantes A, Alfaro G, Méndez JP, Kofman-Alfaro S. Frequency of Y chromosomal material in Mexican patients with Ullrich-Turner syndrome. Am J Med Genet 1998; 76(2): 2120-2124.

6. Lippe B. Turner syndrome. Endocrinol Metab Clin North Am 1991; 20(1): 121-152.

7. Binder G, Koch A, Wajs E, Ranke MB. Nested polymerase chain reaction study of 53 cases with Turner's syndrome: is cytogenetically undetected Y mosaicism common? J Clin Endocrinol Metab 1995; 80(12): 3532-3536.

8. Hook EB, Warburton D. The distribution of chromosomal genotypes associated with Turner's syndrome: livebirth prevalence rates and evidence for diminished fetal mortality and severity in genotypes associated with structural $\mathrm{X}$ abnormalities or mosaicism. Hum Genet 1983; 64(1): 24-27.

9. Held KR, Kerber S, Kaminsky E, Singh S, Goetz P, Seemanova E, Goedde HW. Mosaicism in 45,X Turner syndrome: does survival in early pregnancy depends on the presence of two sex chromosomes? Hum Genet 1992; 88(3): 288-294.

10. Scully RE. Gonadoblastoma. Cancer 1970; 25(6): 1340-1356.

11. Verp MS, Simpson JL. Abnormal sexual differentiation and neoplasia. Cancer Genet Cytogenet 1987; 25(2): 191-218.

12. Tsuchiya K, Reijo R, Page DC, Disteche CM. Gonadoblastoma: Molecular definition of the susceptibility region on the Y chromosome. Am J Hum Genet 1995; 57(6): 1400-1407.

13. Giese K, Cox J, Grosschedl R. The HMG domain of lymphoid enhancer factor 1 bends DNA and facilitates assembly of functional nucleoprotein structures. Cell 1992; 69(1): 185-195.

14. Harley VR, Jackson DI, Hextall PJ, Hawkins JR, Berkovitz GD, Sockanathan S, Lovell-Badge R, Goodfellow PN. DNA binding activity of recombinant SRY from normal males and XY females. Science1992; 255(5043): 453-456.

15. Pontiggia A, Whitfield S, Goodfellow PN, Lovell-Badge R, Bianchi MA. Evolutionary conservation in the DNA-binding and -bending properties of HMG boxes from SRY proteins of primates. Gene 1995; 154(2): 277-280.

16. Sinclair AH, Berta P, Palmer MS, Hawkins JR, Griffiths BL, Smith MJ, Foster JW, Frischauf AM, Lovell-Badge R, Goodfellow PN. A gene from the sex-determining region encodes a protein with homology to a conserved DNA-binding motif. Nature 1990; 346(6281): 240-244.

17. Berta P, Hawkins JR, Sinclair AH, Taylor A, Griffiths BL, Goodfellow PN, Fellous M. Genetic evidence equating SRY and the testis-determining factor. Nature 1990; 348(6300): 448-450.

18. Gubbay J, Collignon J, Koopman P, Capel B, Economou A, Münsterberg A, Vivian N, Goodfellow P, Lovell-Badge R. A gene mapping to the sexdetermining region of the mouse $\mathrm{Y}$ chromosome is a member of a novel family of embryonically expressed genes. Nature 1990; 346(6281): 245-250.

19. Jäger RJ, Anvret M, Hall K, Scherer G. A human XY female with a frame shift mutation in the candidate testis-determining gene SRY. Nature 1990; 348(6300): 452-454.

20. Koopman P, Gubbay J, Vivian N, Goodfellow P, Lovell-Badge R. Male development of chromosomally female mice transgenic for Sry. Nature 1991; 351(6322): 117-121. 
21. Kocova M, Siegel SF, Wenger SL, Lee PA, Trucco M. Detection of Y chromosome sequences in Turner's syndrome by Southern blot analysis of amplified DNA. Lancet 1993; 342(8864): 140-143.

22. Kocova M, Siegel FS. Detection of Y chromosome sequences in a 45,X/46,XXq-patient by Southern blot analysis of PCR-amplified DNA and fluorescent in situ hybridization (FISH). Am J Med Genet 1995; 55(4): 483-488.

23. Poncz M, Solowiejczyk D, Harpel B, Mory Y, Schwartz E, Surrey S. Construction of human gene libraries from small amounts of peripheral blood: analysis of $\beta$-like globin genes. Hemoglobin 1982; 6(1): 27-36.

24. Efremov GD, Dimovski AJ, Plaseska-Karanfilaska D, Simjanovska L, Sukarova E, Koceva S, Popovski ZT. Isolation of genomic DNA from mammalian cells. Laboratory Manual, 2nd ed. Skopje: Macedonian Academy of Sciences and Arts, RCGEB. 1998:1-3.

25. Greer CE, Peterson SL, Kiviat NB, Manos MM. PCR amplification from paraffin-embedded tissues. Effects of fixative and fixation time. Am J Clin Pathol 1991; 95(2): 117-124.

26. Fernandez Garcia R, Garcia Doval S, Costoya S, Pasaro E. Analysis of sex chromosome aneuploidy in 41 patients with Turner syndrome: a study of 'hid- den' mosaicism. Clin Genet 2000; 58(3): 201-208.

27. Kocova M, Witchel SF, Nalesnik M, Lee PA, Dickman PS, MacGillivray MH, Reiter EO, Trucco G, Trucco M. Y Chromosomal sequences identified in gonadal tissue of two 45,X patients with Turner syndrome. Endocr Pathol 1995; 6(4): 311-322.

28. Page DC. Hypothesis: a Y chromosomal gene causes gonadoblastoma in disgenetic gonads. Development 1987; 101(Suppl): 151-155.

29. Medlej R, Lobaccaro JM, Berta P, Belon C, Leheup B, Toublanc JE, Weill J, Chevalier C, Dumas $\mathrm{R}$, Sultan C. Screening for Y-derived sex determining gene SRY in 40 patients with Turner syndrome. J Clin Endocrinol Metab 1992; 75(5): 1289-1292.

30. Yorifuji T, Muroi J, Mamada M, Uematsu A, Kawai M, Momoi T, Kaji M, Yamanaka C, Nakahata T. Analysis of the SRY gene in Turner syndrome patients with Y chromosomal material. J Med Genet 2001; 38(11): E41.

31. Gravholt CH, Juul S, Naeraa RW, Hansen J. Morbidity in Turner Syndrome. J Clin Epidemiol 1998; 51(2): 147-158.

32. Gravholt CH, Fedder J, Naeraa RW, Müller $\mathrm{J}$. Occurrence of gonadoblastoma in females with Turner syndrome and Y chromosome material: a population study. J Clin Endocrinol Metab 2000; 85(9): 3199-3202. 